\title{
Leadership - a critical success factor for the effective implementation of Lean Six Sigma
}

\author{
Alessandro Laureani ${ }^{a} \&$ Jiju Antony ${ }^{b}$
}

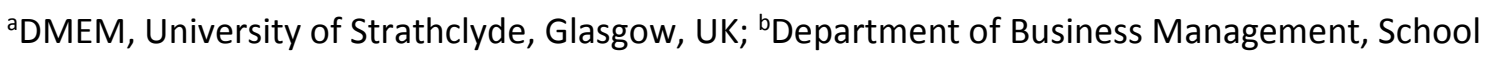
of Management \& Languages, Heriot-Watt University, Edinburgh, UK 


\begin{abstract}
The objective of this paper is to offer further insights into Lean Six Sigma deployment, highlighting the more important critical success factors (CSFs) and particularly the role of leadership in successful deployment. Identification of CSFs for Lean Six Sigma is important as it allows organisations to focus their efforts on these factors to ensure success. The study is in two parts: the first part reviews the literature on leadership, Lean Six Sigma and CSFs for continuous improvement programmes. The second part illustrates the results of a longitudinal study through the administration of a survey questionnaire and exploratory factor analysis of the answers.

The results suggest that the most important and significant factors for the effective implementation of Lean Six Sigma are: project management, leadership, selection of top talented people and financial accountability. Although they highlight the importance of leadership as a critical success factor for effective deployment of Lean Six Sigma, more research is needed to determine what type of leadership is appropriate at different stages of Lean Six Sigma programme maturity.
\end{abstract}

Keywords: Lean, Six Sigma, Leadership, Critical Success Factors 


\section{Introduction}

As the quality of products and services is critical to a firm's success, many attempts have been made over the years to deploy continuous improvement programmes to improve quality, and Lean Six Sigma is one of the most frequently used frameworks for continuous improvement: it is a business improvement methodology that aims to maximise shareholder value by improving quality, speed, customer satisfaction, and costs. While Lean Six Sigma has been successfully deployed in companies success reported by companies-such as Motorola, General Electric, Caterpillar and other global brands has helped to increase its adoption across industries (Desai, 2006), there are may examples of unsuccessful deployment (Chakravorty, 2009) and its. However, Lean Six Sigma implementation is fraught with problems (Gijo \& Rao, 2005). and there are many examples of its unsuccessful deployment in organisations: there is increasing concern about implementation failures (Chakravorty, 2009), and $₹$ Various critical success factors (those factors essential to the success of any program and technique, have been identified and discussed in the literature (Rungasamy, Antony, \& Ghosh, 2002), wih the focus mostly on have been identified and diseussed in the literature.

What makes some continuous improvement programmes successfully transform an organisation and others easily forgotten? For anyone involved in operational excellence, there is probably no more important question. In trying to answer it, most prior studies on critical success factors have focused on techniques or tools to aid the implementation: this study, instead, investigates the influence of leadership on individual quality management practices. This research contributes to the existing literature in two ways: first, it operationalises the many success factors in four critical ones; second, it establishes leadership as one of these four critical success factors.

This contribution not only adds to our understanding of Lean Six Sigma practices but should be of particular interest to industry's community of practice, enlightening Lean Six Sigma practitioners who are in the midst of deployment, or indeed any organisations considering the Lean Six Sigma 
path and wondering what is needed to make it a success: it takes leadership to start a continuous improvement programme and keep it on track despite the many distractions and the resistance met in an organisation. Does the leadership have what it takes?

The paper is structured as follows: the relevant Lean Six Sigma and leadership literature is reviewed in Section 2, and the critical success factors for Lean Six Sigma are illustrated in Section 3. Empirical results are presented in Section 4, and-Section 5 presents a discussion of the findings, research and managerial implications, with the conclusion in Section 6limitations and future research opportunities.

\section{Literature review}

\subsection{Lean Six Sigma}

Lean Six Sigma is a business improvement methodology that aims to maximise shareholder value by improving quality, speed, customer satisfaction, and costs: it achieves this by merging tools and principles from both Lean and Six Sigma. It has been widely adopted in manufacturing and service industries, and its success in some well-known organisations (e.g. GE and Motorola) has created a copycat phenomenon with many organisations around the world anxious to replicate its success.

Lean and Six Sigma have followed independent paths since the 1980s, when the terms were first hard coded and defined: the first applications of Lean were recorded in the Michigan plants of Ford in 1913, and were then further developed in Japan (within the Toyota Production System), whereas Six Sigma saw the light in the United States (at the Motorola Research Center). Lean is a process improvement methodology used to deliver products and services better, faster, and at lower cost. Womack and Jones (1996) defined it as

a way to specify value, line up value-creating actions in the best sequence, conduct those activities without interruption whenever someone requests them, and perform them more 
and more effectively. In short, lean thinking is lean because it provides a way to do more and more with less and less-less human effort, less human equipment, less time, and less space—while coming closer and closer to providing customers with exactly what they want. Six Sigma is a data-driven process improvement methodology used to achieve stable and predictable process results by reducing process variations and defects. Snee (1999) defined it as a business strategy that seeks to identify and eliminate causes of errors or defects or failures in business processes by focusing on outputs that are critical to customers'.

Despite their different origins, Lean and Six Sigma share some commonalities, such as an emphasis on a culture of continuous improvement, customer satisfaction, comprehensive employee involvement and search for root causes. Antony and Kumar (2012) list the following commonalities and differences:

Table 1 Lean and Six Sigma commonalities and differences

Although both Lean and Six Sigma have been used for many years, they were not integrated until the late 1990s and early 2000s (George, 2002, 2003), and today Lean Six Sigma is recognised as 'a business strategy and methodology that increases process performance resulting in enhanced customer satisfaction and improved bottom line results' (Snee, 2010). Lean Six Sigma uses tools from both toolboxes in order to get the best from the two methodologies, increasing speed while also increasing accuracy.

The benefits of Lean Six Sigma in the industrial world (in both manufacturing and services sectors) have been highlighted extensively in the literature (Zhang, Irfan, Khattak, Zhu, \& Hassan, 2012) and include the following (Antony, 2005a, 2005b). 
1. Ensuring services/products conform to what the customer needs ('voice of the customer').

2. Removing non-value adding steps (waste) in critical business processes.

3. Reducing the cost of poor quality.

4. Reducing the incidence of defective products/transactions.

5. Shortening the cycle time.

6. Delivering the correct product/service at the right time in the right place.

One of the key elements differentiating Lean Six Sigma from previous quality initiatives is the organisation and structure of the quality implementation functions. In quality initiatives prior to Lean Six Sigma, the management of quality was relegated largely to the production floor and/or, in larger organisations, to statisticians in the quality department. Instead, Lean Six Sigma introduces a formal organisational infrastructure for different quality implementation roles, borrowing terminology from the world of martial arts to define hierarchy and career paths (Adams, Gupta, \& Wilson, 2003; Antony, Kumar, \& Madu, 2005; Antony, Kumar, \& Tiwari, 2005; Harry \& Schroeder, 2000; Pande, Neuman, \& Cavanagh, 2000; Snee, 2004).

\subsection{Leadership: synthesis of literature research}

Leadership definitions abound in the literature: in 1991, 54 leadership experts from 38 countries agreed on a common definition of leadership: 'Influencing, motivating, and enabling others to contribute toward the effectiveness and success of the organisations of which they are members' (House, Javidan, \& Dorfman, 2001).

The following Tables $2 \underline{a}$ and $2 b$ summarises the leadership traits, and main literature $\underline{\text { references, }}$ for the 10 most common leadership styles identified in the literature (Bass, 1990; 
Hofstede, 1977; Kouzes \& Posner, 1987; Schriesheim, 1982; Stogdill, 1989; Tannenbaum \& Schmitt, 1958)_. Here a brief description for each:

5-Level: the Level 5 leader sits on top of a hierarchy of capabilities and builds enduring company greatness through a paradoxical combination of personal humility plus professional will (Collins, 2001).

Affiliative: a leadership style where the leader promotes harmony among his or her followers and helps to resolve any conflict. This type of leader will also build teams that make sure that their followers feel connected to each other. Typically the followers will receive much praise from this style of leader, but poor performance tends to go unchecked (Goleman, Boyatzis, \& MeKee, 2004).

Bureaucratic: a style of leadership that emphasises procedures and historical methods regardless of their usefulness in changing environments. Bureaucratic leaders attempt to solve problems by adding layers of control, and their power comes from controlling the flow of information (Weber, 1905).

Participative: also known as Democratic style. The leader involves subordinates in goal-setting, problem-solving, team building ete, but retains the final decision-making authority (Lewin, Lippitt, \& White, 1939).

Servant: stresses the importance of the role a leader plays as the steward of the resources of a business or other organisation, and teaches leaders to serve others while still achieving the goals set eut by the business (Greenleaf, 1977).

Six Sigma: advocates a higher standard of leadership effectiveness through the founding principles of Six Sigma, and is a model anyone can aspire to regardless of whether the company uses Six Sigma or not (Pande, 2007). 
Table 2a Leadership traits by leadership style

\section{Table 2b Leadership styles' reference list}

\subsection{Overview of the relationship between leadership and Lean Six Sigma}

Lean Six Sigma has been extremely successful in some organisations, where it is no longer only a cost reduction initiative but has also been embedded into the organisation's way of doing things: more well-known examples are probably Toyota for Lean (Liker, 2003) and GE for Six Sigma (Eckes, 2000). However, many other organisations struggle to turn Lean Six Sigma into a success because of different failure factors (Albliwi, Antony, Halim Lim, \& van der Wiele, 2014), and the question is whether different styles and traits of leadership can have an impact on whether the deployment of Lean Six Sigma results in organisational success. As Deming said (1994), quality is 
determined by top management and cannot be delegated, and the quality of the output of a company cannot be better than the quality at the top (Hilton \& Sohal, 2012; Suresh, Antony, Kumar, \& Douglas, 2012). Existing theory suggests that in order to implement a quality improvement process successfully, an organisation needs to have transformational leaders at the top (Waldman, 1993) to create the culture and objectives which must be adopted by transactional leaders in the middle management ranks (Waldman et al., 1998).

Research shows an inextricable link between leadership and commitment (Aboelmaged, 2011; Martinez-Jurado \& Moyano-Fuentes, 2012; Waldman et al., 1998) at the basis of the success of a quality improvement programme: unwavering commitment to quality programmes from top management is fundamental for embedding those into the organisation's culture, allowing it to overcome the initial scepticism of employees (Bhasin 2012a, 2012b; Juran, 1989).

Leadership has been recognised as a mechanism for embedding cultural values and norms into an organisation (Schein, 1983); at the same time, the idea of culture affecting the type of leadership in an organisation has been advanced (Bass, 1985), suggesting the existence of a reciprocal relationship between leadership and culture in organisations (Waldman, 1993). Overall, Lean Six Sigma deployment needs to proceed hand in hand with cultural change in order to avoid falling into the same traps into which TQM fell in previous generations of quality improvement programmes (Albliwi et al., 2014; Bushe, 1988).

Leadership and organisational culture look at conditions within the organisation, but Forker (1991) noted how societal-level differences exist in the way quality and continuous improvement are defined in the USA, Japan, and what was the USSR at the time his article was written: these societal-level differences have an impact on the organisational culture. Putting all this together, similarly to the TQM model introduced by Waldman (1993), we suggest the model displayed in Figure 1 for illustrating the links between leadership, culture, and Lean Six Sigma. 
Figure 1 Model of leadership, culture and Lean Six Sigma, adapted from Waldman, 1993

This model illustrates the key relationships so far identified in the literature.

1. the reciprocal impact of leadership and culture within the organisation;

2. the societal-level factors outside the organisation that have an impact on the organisational culture;

3. how (A) and (B) above impact on the Lean Six Sigma behaviours of employees affected by both the leadership and the culture prevalent in the organisation;

4. all the above combine to generate the Lean Six Sigma outputs.

\section{Lean Six Sigma: critical success factors (CSFs)}

In this section, we discuss the CSFs for Lean Six Sigma and validate the following hypothesis:

\section{H1. Leadership is one of the main critical success factors for Lean Six Sigma deployment in} organisations.

Rockart (1979) illustrated the concept of CSFs and examined how they can be used to determine the informational needs of managers. According to Rungasamy et al. (2002), CSFs are those factors essential to the success of any programme or technique in the sense that if the objectives associated with the factors are not achieved the application of the technique may fail catastrophically. CSFs include issues vital to an organisation's current activities and future success (Boynlon \& Zmud, 1984).

In the wealth of Lean Six Sigma literature, we identified 31 sources discussing CSFs for its implementation (22 articles and nine books) of which the resulting list of 19 CSFs is summarised in 
Table 2a. Antony and Banuelas (2002) analysed the key ingredients for the effective implementation of a Six Sigma programme in UK companies, and Coronado and Anthony (2002) further refined them to identify the top $10 \mathrm{CSFs}$ encompassing a diverse range of skills from the more technical to leadership ones.

The importance of organisational infrastructure and culture was particularly highlighted by Zu, Robbins, and Fredendall (2010), whereas Pande et al. (2000) included leadership commitment as one of their CSFs. Johnson and Swisher (2003) focused on the training and selection aspect, identifing project selection and training of staff as CSFs, as did Halliday (2001).

Kwak and Anbari (2006) split CSFs into four main areas: management involvement and organisational commitment; project selection, management, and control skills; encouraging and accepting cultural change; and continuous education and training. Similarly, Achanga, Shehab, Roy, and Nelder (2006) identified four CSFs: leadership and management, finance, skills and expertise, and organisational culture. Kumar (2007) identified 13 CSFs for Six Sigma implementation in SMEs. The importance of organisational culture as a CSF was identified by Erwin (2000), and Dale (2000) highlighted the importance of linking Lean Six Sigma to the overall business strategy.

The need for a process management system, particularly for tracking and reviewing projects, was highlighted by Martens (2001), and Ingle and Roe (2001) went deeper into the subject, identifying the prioritisation of projects as a CSF. Antony (2006) added other CSFs to the literature, including selecting team members, understanding tools, linking Six Sigma to customers and accountability to the existing list of CSFs.

Henderson and Evans (2000) identified the following CSFs for Six Sigma: management support, organisational infrastructure, training, tools, and linking Six Sigma to human resources- 
based actions (promotions, bonuses, etc,), whereas, in an appeal to statisticians, Hahn, Hill, Hoerl, and Zinkgraf (1999) identified leadership, training, and project involvement as CSFs.

Table 3a Summary of the CSFs from the literature

Table 3b Leadership literature references

\section{Research methodology and data collection}

\subsection{Research Framework}

Understanding the research framework and the more appropriate methodology for the study is a critical aim of researchers: the starting point of any research is to understand the nature of the research problem, leading to the choice of an appropriate research methodology (Rowlands, 2005). It is important to have a clear statement of purpose for the research (Yin, 2003): in this research we are taking an exploratory approach, focusing on what critical success factors apply to Lean Six Sigma, trying to identify the relationships shaping the phenomenon of Lean Six Sigma deployment in organizations. The study was conducted on an epistemiological positivist stance, with the researcher assuming the role of an objective analyst, making detached interpretations through test on data collected in a value-free manner (Saunders, Lewis \& Thornhill, 2003).

\subsection{Research Methodology}

$\underline{\text { In management research, different methodologes are commonly used, and choosing the most }}$ appropriate one depends on the research's questions and objectives (Saunders, Lewis \& Thornhill, 2003). The purpose of this study was to verify whether companies that implement Lean Six Sigma still recognise the same set of CSFs individuated in the literature and which they consider to be most important. To answer this question, a structured questionnaire, administered via email, was used. Survey research has been the most commonly used research method since the 1990s (Kumar, 2010; Meredith, Raturi, Amoako-Gympah, \& Kaplan, 1989) and has become the dominant form of 
data collection in the social sciences, providing for efficient data collection over broad populations, administered in person, by telephone or over the internet (Easterby-Smith, Thorpe, \& Lowe, 2002). Bryman (1988, p.104) defined survey research as follows:

Survey research entails the collection of data on a number of units and usually at a single juncture in time, with a view to collecting systematically a body of quantifiable data in respect of a number of variables which are then examined to discern patterns of association. It is a structured data collection technique whereby information about a person's perceptions, beliefs, feelings, motivations, anticipation, or future plans can be obtained (Antony, Antony, Kumar, \& Cho, 2007), with the advantage that the respondents are asked exactly the same set of questions, thus enabling the statistical analysis of the results.

\section{4. $\underline{3}$ Survey structure}

The survey used in this research was comprised of 18 questions, covering the background of respondents and organisations, criteria for the successful implementation of Lean Six Sigma in an organisation and CSFs for Lean Six Sigma implementation.

The first part of the questionnaire collected information on the seniority of the respondent, the size, location and sector of the organisation, and the extent of use of Lean Six Sigma in the organisation. The second part of the questionnaire investigated the success metrics used in the organisation to determine whether the Lean Six Sigma efforts were successful, and asked the respondent to evaluate the programme's success so far. Finally, in the last section of the questionnaire, each respondent was asked to rank the 19 critical success factors outlined in the literature, or suggest new one(s) if they felt any was missing.

\section{4.르 Type of questions}


In the design of any survey, the response format is a major consideration, as it will affect the type and wording of the questions and the type of analysis that can be conducted subsequently (Fowler, 2002). For this research a close-ended question format was used to allow for statistical analysis. In the last part of the questionnaire, the 19 CSFs from the literature were operationalised on a fivepoint Likert scale $(1=$ Not Very Important; 2=Not Important; 3=Important; 4=Very Important; 5=Critical), and respondents were asked to rank each factor from 1 to 19 (1=most important, $2=$ second most important, etc.) in order to identify the importance of these 19 CSFs. The Likert scale provides a more precise measurement than yes/no type of questions (Neuman, 2003). The data collected were then analysed with Microsoft Excel and SPSS software.

\subsection{Sampling method and procedure}

The questionnaire was distributed electronically to 700 Lean Six Sigma professionals from various industries and countries: the list of companies was obtained from the database of the Department of Design, Manufacturing, and Engineering Management of Strathclyde University, plus a network of the professional contacts of the research team. The response rate was $20.5 \%$, with 123 responses received: this was deemed satisfactory, as according to the maximum likelihood estimation (MLE), in order for the sample to be effectual the number of respondents should be between 100 and 10 (Ding, Velicer, \& Harlow, 1995). The questionnaire was targeted at those organisations, irrespective of industry sector, that had already implemented either Lean or Six Sigma or Lean Six Sigma.

\section{4ㅁ Analysis of survey results \\ 4.64.1 Demographics}

The analysis of the first part of the questionnaire provided a better understanding and context of the key findings of the study. 
The majority of respondents were either master black belts (25\%), black belts $(24 \%)$, or function leads / managers (16\%) in companies which mostly had more than 1,000 employees (70\%) who responded to the survey. Of the 20 areas of industry selected for this survey, industrial goods \& services, financial services, automotive, and computer \& services accounted for $40 \%$ of total responses. Almost half (48\%) of the companies had implemented Lean Six Sigma for cost savings or cost avoidance (e.g. less waste, inventory levels): this was by far the most cited reason for implementation, followed at some distance by productivity increases (18\%) and customer satisfaction (13\%). More than half of companies (58\%) used Lean and Six Sigma together in tandem, $22 \%$ used Lean on its own, and only $11 \%$ used Six Sigma on its own. A third of respondents' companies applied Lean Six Sigma to all their business units, with half applying it to more than one business unit. The business units cited more frequently as implementing Lean Six Sigma were operation / production, supply chain, logistics, finance, and customer service. Twothirds $(66 \%)$ of respondents considered the implementation of Lean Six Sigma to be either successful or extremely successful; about $3 \%$ considered it to be either unsuccessful or extremely unsuccessful, with the remaining $31 \%$ observing no significant impact either way.

\section{64.2 Reliability test}

In order to measure the consistency of the survey, a reliability test was conducted. Reliability offers 'an indication of consistency between two measure of the same thing' (Black, 1999). According to Cramer (1998), 'reliability is particularly important in connection with multiple item scales', and he indicated three main types of tests for assessing data reliability: Cohen's kappa coefficient, Ebel's intraclass correlation, and Cronbach's alpha coefficient. Cronbach's alpha coefficient is the most widely used (Black, 1999), and this was therefore calculated with JMP software: an alpha 
coefficient of 0.6 or higher is considered to be an acceptable level of internal consistency. The results indicated an overall Cronbach's coefficient of 0.855 ; hence, we could infer that the data collected were suitable for analysis.

\subsection{Analysis of CSFs}

Respondents to the survey were asked to score on a Likert scale their perceived importance of each CSF, with 1=Not Very Important; 2=Not Important; 3=Important; 4=Very Important; 5=Critical. A factor with the highest mean score was considered to be the most important factor.

The t-tests indicated no significant differences among demographic variables (at the 95\% significance level), including the number of employees in the organisation or whether the organisation implemented only Lean, only Six Sigma, or the two together, meaning respondents from different-sized organisations and those that implemented either Lean or Six Sigma first answered in a similar way.

As the survey was longitudinal in nature, spread over time, the difference between early and late respondents was tested (Armstrong \& Overton, 1997). The final sample was split into two depending on the dates the questionnaires were received: the earlier group consisted of the replies received after the first two distributions of the survey, whereas the second group included the replies received after the fourth email: the $\chi^{2}$ test yielded no statistically significant differences (at the $95 \%$ significance level).

\subsection{Exploratory factor analysis (EFA)}

An EFA (Norris \& Lecavalier, 2010) was utilised to analyse the results of the survey. Factor analysis is a family of statistical methods whose goal is to identify the underlying relationships between variables: as per Finch and West (1997), EFA is the most appropriate technique when there is no a priori hypothesis abut factors or patterns of measured variables; it is used to determine the number of latent variables (factors) that are needed to explain the correlations among a set of 
observed variables. In this case, we applied it to the 19 CSFs to determine the existence of any underlying relationships.

EFA has four assumptions: variables are normal, have a linear relation, have a minimum amount of correlation and have a sample size with a cases/items ratio of at least 5:1 (for the 19 CSFs in our study-, that implied at least 95 responses). These assumptions were tested in SPSS for the data set.

The first step in the EFA was to measure the associations between variables by using a correlation matrix. Two factors (Lean Six Sigma training and awareness) had cummonalities greater than one, and hence they were removed from the model: communality is the percentage of variance in a given variable explained by all the factors jointly; a communality $>1$ is an indication of a spurious solution, reflecting too many factors, that can therefore be eliminated (Gorsuch, 1983).

The model resulting from the remaining 17 factors had the following correlation matrix (Table 3), where all communalities are $<1$ :

Table 4 Correlation matrix

We then used Kaiser's (1960) eigenvalue-greater-than-one rule (also known as the K1 rule) to determine the factors to be included in the model: the eigenvalue of a factor represents the amount of variance of the variables accounted for by that factor: the lower the eigenvalue, the less that factor contributes to the explanation of variances in the variables (Norris \& Lecavalier, 2010). Usually, factors with eigenvalues greater than one are deemed to be significant (Zwick \& Velicer, 1986).

Calculation of eigenvalues was performed in SPSS and four factors were found to have eigenvalues greater than one, explaining $55 \%$ of the variance (Table 5).

Table 5 Total variance explained

16 
Finally, we used the pattern matrix to group the 17 CSF variables around the four factors on the basis of their factor loadings: the factor loadings are the correlation coefficients between the variables and the factors, indicating the percentage of variance in each variable explained by each factor. Higher factor loading indicates that a variable is highly correlated with the relevant factor, allowing the grouping of variables around the main four factors (Table 6).

\section{Table 6 Pattern matrix}

Matching each variable to the factors for which it has the highest factor loading, we could then suggest the following composition for each factor.

- Factor 1 includes project management skills, LSS project selection and prioritisation, organisational infrastructure, tools and techniques, extending Lean Six Sigma to the supply chain, data-based approach, linking Lean Six Sigma to HR rewards, and project tracking and review. All these relate to the sphere of managing projects, and we can thus refer to the factor as 'project management'.

- Factor 2 includes management commitment, linking LSS to customers, linking LSS to business strategy, leadership style, communication, and cultural change. All these are either leadership traits (style, communication, and commitment) or leadership priorities (linking Lean Six Sigma to strategy and customers): we can thus refer to this factor as 'leadership'.

- Factor 3 includes the selection of LSS staff and resources for LSS staff. We can refer to this as 'selection of top talented people'.

- Factor 4 is about the overall financial accountability of the Lean Six Sigma programme. We can refer to this as 'financial accountability'. 


\begin{abstract}
Project management, leadership, selection of top talented people, and financial accountability are the four significant factors for a successful Lean Six Sigma implementation, confirming our initial hypothesis on leadership being a critical success factor for Lean Six Sigma deployment.
\end{abstract}

\title{
5. Discussion and implications
}

\subsection{Implications for practice}

The study presented here draws a more complete picture of the citical success factors for Lean Six Sigma deployment in organisations: this research adds to the theory of Lean Six Sigma by highlighting and investigating the role of leadership in driving organisational deployment, confirming the hypothesis that leadership is indeed a critical success factor for the deployment of Lean Six Sigma in organisations. The four factors identified as significant all have managerial implications for the practice of Lean Six Sigma, and provide a solid framework for organisations about to start deployment:

- Project management: for Lean Six Sigma deployment to be successful, it is important to work on projects aligned to the business strategy, so as to show immediate value to the organisation at large. Accurate data-driven tracking of projects is necessary to ensure deployment stays on track, as well as reward success among employees (Duarte, Montgomery, Fowler, \& Konopka, 2012; Kornfeld \& Kara, 2013).

- Leadership: as we have seen from the literature review, leaders have many different traits and styles. These results suggest that successful leadership is:

- committed to processing improvement in general and Lean Six Sigma specifically, as suggested by Dale and Lightburn (1992). Lean Six Sigma transformation is a journey that does not happen overnight: successful leaders are those that can see beyond the 
difficulties and inspire employees to keep going (Hilton \& Sohal, 2012; Jokinen, 2005; Suresh et al., 2012);

- able to see the link between Lean Six Sigma and the overall business strategy and its customers as well as communicate this to employees in a clear and compelling vision (Hilton \& Sohal, 2012; Sumukadas, 2006; Suresh et al., 2012);

- able to establish an organisational culture that accelerates Lean Six Sigma implementation (Taylor \& Wright, 2003);

- and that visible, inspirational, realistic, targeted and consistent leadership is necessary to carry the organisation forward (Kausman \& Lane, 2008).

- Selection of top talented staff: although it is rather typical of organisations that the oldest or the most experienced professionals are in positions of leadership (Kulmala, Ahonemi, \& Nissinen, 2009), this study highlights the importance of involving the top talent in the organisation in Lean Six Sigma, providing them with the right project management tools and making them financially accountable for the success of their intiatives (Panizzolo, Garengo, Sharma, \& Gore, 2012).

- Financial accountability: it is necessary to keep the Lean Six Sigma efforts linked to the financial results of the organisation, making leaders accountable for the financial impacts of their initiatives.

\subsection{Implications for research and limitations}

Like any research, this study has a number of limitations which present interesting future research opportunities. The study focuses on the impact of leadership on Lean Six Sigma deployment, but it does not go into the specifics of separating the types of leadership needed from senior management versus that needed from middle management: more research is needed to investigate whether there 
is any significant difference between the two and their influence on Lean Six Sigma implementation.

There is also an opportunity for empirical research to determine which leadership style is most conducive to successful deployment. Bremer, Daniels, Gupta, and McCarty (2005) suggested that Six Sigma leadership utilises both transactional and transformational forms of leadership, and Pande (2007) suggests the need to go beyond these traditional forms of leadership; an empirical investigation that correlates leadership traits with the success, or lack of success, of the Lean Six Sigma programme in organisations may be needed to close this gap.

Future research must also empirically investigate which type of leadership is more appropriate at different stages of Lean Six Sigma programme maturity: is the leadership style needed to support the start of such a programme the same as that needed to sustain the same deployment later on?

\section{Conclusion}

Lean Six Sigma is an evolving quality management practice that has attracted both academics and practitioners thanks to its documented success. It was the objective of this paper to obtain further insights into Lean Six Sigma deployment, highlighting the more important critical success factors (CSFs) and particularly the role of leadership in successful deployment. Although many CSFs have been identified in the Lean Six Sigma literature, few studies have highlighted the role of leadership, which is key to Six Sigma success (Hoerl \& Snee, 2003).

The study also has broader implications for managers and Lean Six Sigma practitioners who deploy quality improvement programmes in the hope that these programmes will enhance performance and outweigh the investment made (Arumugam, 2012): this study highlights the importance of putting the right leadership in place to ensure successul deployment, coupled with the top talent in the 
organisation involved in Lean Six Sigma, providing them with the right project management tools, and making them financially accountable for the success of their initiatives.

Overall, organisations need to make sure they have in place leaders committed to inspiring employees and establishing the right culture for continous improvement in order to reap the benefits of Lean Six Sigma deployment. 


\section{References}

Aboelmaged, M.G. (2011), "Reconstructing Six Sigma barriers in manufacturing and service organizations: the effects of organizational parameters", International Journal of Quality \& Reliability Management, Vol. 28 No. 5, pp. 519-541.

Antony, J., Antony, F. J., Kumar, M. \& Cho, B.R. (2007), "Six Sigma in service organizations benefits, challenges and difficulties, common myths, empirical observations and success factors", International Journal of Quality \& Reliability Management, Vol. 24, No. 3, pp. 294-311

Aboelmaged, M.G. (2011), "Reconstructing Six Sigma barriers in manufacturing and service organizations: the effects of organizational parameters", International Journal of Quality \& Reliability Management, Vol. 28 No. 5, pp. 519-541.

Achanga, P., Shehab, S., Roy, R., \& Nelder, G. (2006). "Critical success factors for lean implementation within SMEs”, Journal of Manufacturing Technology Management, Vol. 17, No.

(4), pp. $460-471$.

Adams, C., Gupta, P. \& Wilson, C. (2003), Six Sigma deployment, Burlington, MA, ButterworthHeinemann.

Albliwi S., Antony J., Halim Lim, S.A. \& van der Wiele, T. (2014),"Critical failure factors of Lean Six Sigma: a systematic literature review", International Journal of Quality \& Reliability Management, Vol. 31, No. 9, pp. 1012 - 1030

Antony, J. \& Kumar, M. (2012), "Lean and Six Sigma Methodologies in NHS Scotland: an empirical study and directions for future research", Quality Innovation Prosperity, Vol. 16, No. 2, pp. 19-34

Antony, J. (2005a), "Assessing the status of six sigma in the UK service organizations", Proceedings of the Second National Conference on Six Sigma, Wroclaw, pp. 1-12. 
Antony, J. (2005b), “Six Sigma for service processes”, Business Process Management Journal, Vol. 12, No. 2, pp. 234-248.

Antony, J. (2006) “Six Sigma for Service processes”, Business Process Management Journal, Vol. 12, No. 2, pp. 234-248

Antony, J. and Banuelas, R. (2002), "Key ingredients for the effective implementation of six sigma program”, Measuring Business Excellence, Vol. 6 No. 4, pp. 20-27.

Antony, J., Antony, F., Kumar, M. and Byung, R.C. (2007) "Six Sigma in service organizations. Benefits, challenges and difficulties, common myths, empirical observations and success factors". International Journal of Quality and Reliability Management, Vol. 24, No. 3, pp. 294-311

Antony, J., Kumar, M. \& Madu, C.N. (2005), "Six Sigma in small and medium sized UK manufacturing enterprises: some empirical observations", International Journal of Quality \& Reliability Management, Vol. 22, No. 8, pp. 860-874.

Antony, J., Kumar, M. \& Tiwari, M.K. (2005), “An application of Six Sigma methodology to reduce the engine overheating problem in an automotive company", IMechE - Part B, 219(B8), 633-646.

Armstrong, J.S., Overton, T.S., 1977. Estimating nonresponse bias in mail surveys. Journal of Marketing Research 14 (3), 396-402.

Arumugam, V., Antoy, J. \& Kumar, M. (2012), "Linking learning and knowledge creation to project success in Six Sigma projects: an empirical investigation", International Journal of Production Economics, Vol. 141, No. 1, pp. 388-402

Bass, B. M. (1985) Leadership and performance beyond expectations, New York: Free Press

Bass, Bernard B. M. (1990), "From transactional to transformational leadership: learning to share the vision", Organizational Dynamics, Vol. 18, No. 3, pp. 19-31. 
Bhasin, S. (2012a), “An appropriate change strategy for lean success”, Management Decision, Vol. 50 No. 3, pp. $439-458$.

Bhasin, S. (2012b), "Prominent obstacles to lean", International Journal of Productivity and Performance Management, Vol. 61 No. 4, pp. 403-425.

Black, T.R. (1999) Doing quantitative research in the social sciences - an integrated approach to the research design: measurement and statistics, Sage Publications, Beverly Hills, CA

Boynlon, A.C. and Zmud, R.W. (1984) "An Assessment of Critical Success Factors", Sloan Management Review, Vol. 25, No. 4, pp. 17-27

Bremer, M., Daniels, L., Gupta, P. \& McCarty, T. (2005) Th Six Sigma Black Belt Handbook, New York: The McGraw-Hill Companies

Breyfogle, F.W. et al. (2001), Managing six sigma: a practical guide to understanding. Assessing and Implementing the Strategy that Yield Bottom-line Success, Wiley, New York, NY.

Brue, G., 2002. Six Sigma for Managers. McGraw-Hill, New York

Brun, A. (2011), "Critical Success Factors of Six Sigma implementations in Italian companies", International Journal of Production Economics, Vol. 131, No. 1, pp. 158-164

Bryman, A. (1988), Quantity and quality in social research. London: Unwin Hyman.

Burns, J. M. (1978) Leadership, New York: Harper \& Row

Burton, T.T. \& Sams, J.L, Six Sigma for Small and Mid-sized Organizations, Florida: J. Ross Publishing, 2005

Bushe, G. R. (1988) "Cultural contradictions of statistical process control in American manufacturing organizations", Journal of Management, Vol. 14, pp. 19-31 
Chakravorty, S. (2009), "Six Sigma programs: an implementation model”, International Journal of Production Economics, Vol. 119, No. 1, pp. 1-16

Collins, J. (2001) Good to Great, New York: HarperCollins Publishers Inc.

Coronado, R. B. \& Antony, J. (2002) “Critical success factors for the successful implementation of six sigma projects in organizations", The TQM Magazine, Vol. 14, No. 2, pp. 92-99

Cramer, D. (1998), Fundamental Statistics for Social Research, Routledge, London

Dale, B. (2000) "Marginalisation of quality: is there a case to answer", The TQM Magazine, Vol. 12, No. 4, pp. 266-274

Dale, B.G. \& Lightburn, K. (1992), “Continuous quality improvement: why some organizations lack commitment”, International Journal of Production Economics, Vol. 27, No. 1, pp. 57-67

Das, A., Kumar, V. \& Kumar, U. (2010), “The role of leadership competencies for implementing TQM - an empirical study in Thai maufacturing industry", International Journal of Quality \& Reliability Management, Vol. 28, No. 2, pp. 195-219

Deming, W. E. (1994) “Leadership for quality”, Executive Excellence, Vol. 11, No. 6, pp. 3-5

Desai, D.A. (2006.) "Improving customer delivery commitments the Six Sigma way: case study of an Indian small scale industry", International Journal of Six Sigma and Competitive Advantage, Vol. 2, No. 1, pp. 23-47.

Ding, L., Velicer, W. \& Harlow, L. (1995), "Effects of estimation methods, number of indicators per factor and improper solutions on structureal equation modeling fit indices", Structural Equation Modeling, Vol. 2, pp. 119-43 
Duarte, B., Montgomery, D., Fowler, J. and Konopka, J. (2012), "Deploying LSS in a global enterprise - project identification", International Journal of Lean Six Sigma, Vol. 3 No. 3, pp. 187 205.

Easterby-Smith, M., Thorpe, R. and Lowe, A. (2002). Management Research-An Introduction. 2nd ed., London: Sage Publication, ISBN 0761978846

Eckes, G. (2000) The Six Sigma Revolution, John Wiley and Sons, New York, NY

Erwin, J. (2000) "It's not difficult to change company culture", Supervision, Vol. 61, No. 11, pp. 611

Finch, J.F. \& West, S.G. (1997), The investigation of personality structure: statistical models, Journal of Research in Personality, Vol. 31, No. 4, pp. 439-485

Forker, L. B. (1991), “Quality: American, Japanese, and Soviet perspectives”, The Executive, Vol. 5, No. 4, pp. 63-74

Fowler, F.J. (2002), Survey Research Methods, 3rd ed., Sage Publications, London

Gardiner, J.J. (2006), “Transactional, Transformational, and Transcendent Leadership: metaphors mapping the evolution of the theory and practice of governance", Leadership Review, Vol. 6, pp.6276

George, M.L. (2002) Lean Six Sigma - Combining Six Sigma Quality with Lean Speed. New York, NY, McGraw-Hill.

George, M.L. (2003) Lean Six Sigma for Service - How to Use Lean Speed and Six Sigma Quality to Improve Services and Transactions. New York, NY, McGraw-Hill.

Gijo, E.V., Rao, T.S., 2005. Six Sigma implementation-hurdles and more hurdles. Total Quality Management 16 (6), 721-725. 
Goldstein, M. "Six Sigma Program Success Factors”, ASQ Six Sigma Forum Magazine, November 2001

Goleman, D., Boyatzis, R. \& McKee, A. (2004), The New Leaders: Transforming the Art of Leadership, Harvard Business Review Press

Gorsuch, R. L. (1983), Factor Analysis, Hillsdale, New Jersey, Lawrece Elbaum Associates.

Greenleaf, R. (1977), Servant Leadership - A Journey into the Nature of Legitimate Power Greatness, Paulist Press

Hahn, G. J., Hill, W. J., Hoerl, R. W. \& Zinkgraf, S. A. (1999), "The impact of six sigma improvement - a glimpse into the future of statistics", The American Statistician, Vol. 53, No. 3, pp. $208-215$

Halliday, S. (2001) “So what is exactly...six sigma?”, Works Management, Vol. 54, No. 1, pp. 15

Harry, M. and Schroeder, R. (2000) Six Sigma - The Breakthrough Management Strategy Revolutionizing the World's Top Corporations. New York, NY, Doubleday.

Hayes, B.J. 2002, Six sigma critical success factors, iSixSigma, viewed 27 Nov 2011, http://www.isixsigma.com/index.php?option=com k2\&view=item\&id=1300\&Itemid $=156$

Henderson, K. \& Evans, J. (2000) "Successful implementation of Six Sigma: benchmarking General Electric Company”, Benchmarking and International Journal, Vol. 7, No. 4, pp. 260-281

Hendricks, C. \& Kelbaugh, R. (1998) “Implementing Six Sigma at GE”, The Journal of Quality and Participation, Vol. 21, No. 4, pp. 48-53

Hilton, R.J. and Sohal, A. (2012), “A conceptual model for the successful deployment of Lean Six Sigma”, International Journal of Quality \& Reliability Management, Vol. 29 No. 1, pp. 54-70.

Hoerl, R. \& Snee, R. (2003), Leading Six Sigma, New Jersey: Financial Times Prentice Hall 
Hofstede, Geert G. (1977). Culture and Organizations: Software of the Mind, New York: McGrawHill.

House, R., Javidan, M. \& Dorfman, P. (2001) "Project Globe: An Introduction", Applied Psychology: An International Review, Vol. 50, pp. 489-505

Ingle, S. \& Roe, W. (2001) “Six Sigma”, “Black Belt Implementation”, The TQM Magazine, Vol. 13, No. 4, pp. 273-280

Johnson, A., Swisher, B., (2003) "How six sigma improves R\&D”, Research Technology Management, Vol. 46, No. 2, pp. 12-15

Jokinen, T. (2005), “Global leadership competencies: a review and discussion", Journal of European Industrial Training, Vol. 29, No. 3, pp. 199-216

Juran, J. M. (1989) Juran on leadership for quality: an executive handbook, New York: Free Press

Kaiser, H.F. (1960), “The applcation of electronic computers to factor analysis", Educational and Psychological Measurement, Vol. 20, pp. 141-151

Kausman, D. \& Lane, A. (2008) "Delivering high performance through continuous improvement: not just any kind of leadership will do!”, The European Business Review, July 2008

Keller, P.A., 2001. Six Sigma Deployment: A Guide for Implementing Six Sigma in Your Organization. Quality Publishing, Tucson

Kornfeld, B. \& Kara, S. (2013), "Selection of Lean and Six Sigma projects in industry", International Journal of Lean Six Sigma, Vol. 4 No. 1, pp. 4-16.

Kouzes, James M. \& Posner, Barry Z. (1987). The Leadership Challenge, San Francisco: JosseyBass. 
Kulmala, H., Ahonemi, L. \& Nissinen, V. (2009), "Performance through measuring leader's profiles: an empirical study", International Journal of Production Economics, Vol. 122, No. 1, pp. $385 / 394$

Kumar, M. (2007), “Critical success factors and hurdles to Six Sigma implementation: the case of a UK manufacturing SME”, International Journal of Six Sigma and Competitive Advantage 2007, Vol. 3, No. 4 pp. 333-351

Kumar, M. (2010), Six Sigma Implementation in UK manufacturing SMEs, PhD Thesis, Glasgow: University of Strathclyde

Kwak, Y.H., Anbari, F.T. (2006) "Benefits, obstacles, and future of Six Sigma approach", Technovation, Vol. 26, No. 5-6, pp. 708-715.

Lewin, K., Lippitt, R. \& White, R.K. (1939) "Patterns of aggressive behavior in experimentally created social climates" Journal of Social Psychology, Vol. 10, pp. 271-301

Liker, J., 2003, The Toyota way, 1st ed. New York, NY: McGraw-Hill

Martens, S.L., 2001. Operationally deploying Six Sigma. Annual Quality Congress 55, 751-755

Martinez-Jurado, P.J. and Moyano-Fuentes, J. (2012), "Key determinants of lean production adoption: evidence from the aerospace sector", Production Planning \& Control: The Management of Operations, Vol. 25 No. 4, pp. 332-345

Meredith, J.R., Raturi, A., Amoako-Gympah, K., and Kaplan, B. (1989), Alternative research paradigms in operation, Journal of Operations Management, Vol. 8, No. 4: pp. 297-326

Neuman, W.L. (2003), Social Research Methods: Qualitative and Quantitative Approaches, 5th ed., Pearson Education, Harlow 
Norris, M. \& Lecavalier, L. (2010) "Evaluating the use of exploratory factor analysis in development disability psychological research", Journal of Autism and Developmental Disorders, Vol. 40, No. 1, pp. 8-20

Pande, P. S. (2007) The Six Sigma Leader, New York: McGraw-Hill

Pande, P., Neuman, R. and Cavanagh, R. (2000) The Six Sigma Way: How GE, Motorola and Other Top Companies Are Honing their Performance. New York, NY, McGraw-Hill Professional.

Panizzolo, R., Garengo, P., Sharma, M.K. and Gore, A. (2012), "Lean manufacturing in developing countries: evidence from Indian SMEs", Production Planning \& Control: The Management of Operations, Vol. 23, No. 10-11, pp. 769-788.

- $\quad$ Revere, L., Kadipasaoglu, S. N. \& Zalila, F. (2006), "An empirical investigation into Six Formatted: Space After: $10 \mathrm{pt}$, No bullets or numbering

Sigma critical success factors", International Journal of Productivity and Quality Management, Vol. 1, No. 3, pp. 224-252

Rockart, J.F. (1979) “Chief executives define their own data needs”, HBR, Vol. 57, No. 2, pp. 238 241

Rowlands, B.H. (2005), "Grounded in Practice: Using Interpretive Research to Build Theory", Electronic Journal of Business Research Methodology, Vol. 3, No. 1, pp. 81-92

Rungasamy, S., Antony, J. \& Ghosh, S. (2002) "Critical success factors for SPC implementation", The TQM Magazine, Vol. 14, No. 4, pp. 217-224

Saunders, M., Lewis, P. \& Thornhill, A. (2003), Research Methods for Business Students, Prentice-Hall, London

Schein, E. H. (1983) "The role of the founder in creating organizational culture", Organizational Dynamics, Vol. 12, pp. 13-28 
Schriesheim, C. A. (1982) "The Great High Consideration- High Initiating Structure Leadership Myth: Evidence on its Generalizability”, The Journal of Social Psychology, No. 116, pp. 221-228.

Sivakumar, S. \& Muthusamy, K. (2011), “Critical success factors in Six Sigma implementation - A case study of MNCs in Malaysia”, Quality \& Reliability (ICQR), 2011 International Conference, Sep 2011, pp. 536-540

Snee, R. D. \& Hoerl, R. W. (2002) Leading Six Sigma: a step-by-step guide based on experience with GE and other six sigma companies. New Jersey: FT Prentice Hall

Snee, R. D. (1999) Why should statisticians pay attention to Six Sigma? Quality Progress, 32(9), $100-103$.

Snee, R. D. (2010) Lean Six Sigma - getting better all the time, International Journal of Lean Six Sigma, 1(1), 9-29.

Snee, R.D. (2004), "Six Sigma: the evolution of 100 years of business improvement methodology", International Journal of Six Sigma and Competitive Advantage, Vol. 1, No. 1, pp. 4-20

Stogdill, R. M.(1989). Stogdill's Handbook of Leadership: A Survey of Theory and Research. Bass, B. (ed.) New York: Free Press.

Sumukadas, N. (2006), "Employee involvement: a hierarchical conceptualisation of its effect on quality", International Journal of Quality \& Reliability Management, Vol. 23, No.2, p. 143-161

Suresh, S., Antony, J., Kumar, M. and Douglas, A. (2012), "Six Sigma and leadership: some observations and agenda for future research", The TQM Journal, Vol. 24 No. 3, pp. 231-247.

Tannenbaum, A.S. and Schmitt, W.H. (1958). How to choose a leadership pattern. Harvard Business Review, 36, March-April, 95-101 
Taylor, W.A. \& Wright, G.H. (2003), “The impact of senior managersà commitment on the success of TQM programes: an empirical study", International Journal of Manpower, Vol. 24, No. 5, pp. $535-550$

Tranfield, D., Denyer, D. \& Smart, P. (2002) Undertaking Research: developing an evidence-based approach for management research. Conference Paper, August, Denver, CO: Academy of Managemen

Waldman, D. A. (1993) "A theoretical consideration of leadership and total quality management", Leadership Quarterly, Vol. 4, No. 1, pp. 65-79

Waldman, D. A. et al. (1998) "A qualitative analysis of leadership and quality improvement", Leadership Quarterly, Vol. 9, No. 2, pp. 177-201

Waldman, D.A., Ramirez, G.G., House, R.J. and Puranam, P. (2001), "Does leadership matter? CEO leadership attributes and profitability under conditions of perceived environmental uncertainty", Academy of Management Journal, Vol. 44, pp. 134-43.

Weber, M. (1905), The Protestant Ethic and the Spirit of Capitalism: and Other Writings. New York: Penguin Group.

Womack, J. P. and Jones, D. T. (1996) Lean Thinking. New York, NY, Simon \& Schuster.

\section{Yin, R.Y. (2003), Case Study Research, 3rd Ed., California, USA: Sage Publication Inc.}

Zhang, Q., Irfan, M., Khattak, M., Zhu, X. \& Hassan, M. (2012), "Lean Six Sigma: A Literature Review", Interdisciplinary Journal of Contemporary Research in Business, Vol. 3, No. 10, pp. 599605

Zu, X., Robbins T.L. \& Fredendall, L.D. (2010) "Mapping the critical links between organizational culture and TQM/Six Sigma practices", International Journal of Production Economics, Vol. 123, No. 1, pp. 86-106 
1

2

3

4

5

6

7

8

9

10

11

12

13

14

15

16

17

18

19

20

21

22

23

24

25

26

27

28

29

30

31

32

33

34

35

36

37

38

39

40

41

42

43

44

45

46

47

48

49

50

51

52

53

54

55

56

57

58

59

60

Zwick, W. R., \& Velicer, W. F. (1986) "Comparison of five rules for determining the number of components to retains”, Psychological Bulletin, Vol. 99, pp. 432-442. 


\begin{tabular}{|l|l|}
\hline \multicolumn{2}{|c|}{ Lean } \\
\hline \multicolumn{2}{|c|}{ Both are continuous business process improvement methodologies } \\
\hline \multicolumn{2}{|c|}{ Both focus on business needs defined by the customer } \\
\hline \multicolumn{2}{|c|}{ Both are practical methods, proven to work in many organisations } \\
\hline \multicolumn{2}{|c|}{ Both involve a comprehensive toolkit for tackling process related problems } \\
\hline $\begin{array}{l}\text { Lean is primarily good for quick and } \\
\text { initial round of improvements }\end{array}$ & $\begin{array}{l}\text { Six Sigma is suitable for long-term and } \\
\text { complex problems where the solutions are } \\
\text { either unknown or vaguely known. }\end{array}$ \\
\hline $\begin{array}{l}\text { Lean requires low investment due to the } \\
\text { nature of the training and the skills to be } \\
\text { developed as a result of this training }\end{array}$ & $\begin{array}{l}\text { Six Sigma demands high investment and is } \\
\text { not suitable for fixing common sense } \\
\text { problems in the business }\end{array}$ \\
\hline $\begin{array}{l}\text { Lean has less emphasis on statistical } \\
\text { tools and techniques }\end{array}$ & $\begin{array}{l}\text { Six Sigma requires the use of applied } \\
\text { statistical methods for understanding and } \\
\text { reducing variation in processes }\end{array}$ \\
\hline $\begin{array}{l}\text { No formal organizational infrastructure } \\
\text { for Lean implementation and deployment } \\
\text { process and uses value stream exercises } \\
\text { to understand the interactions between } \\
\text { processes }\end{array}$ & $\begin{array}{l}\text { Sigma has a well defined organizational } \\
\text { infrastructure (yellow belts, green belts, } \\
\text { black belts, master black belts, deployment } \\
\text { champions and sponsors in some cases) } \\
\text { solving scenario and this would possibly } \\
\text { sub-optimize } \\
\text { performance }\end{array}$ \\
\hline
\end{tabular}




\begin{tabular}{|c|l|}
\hline Leadership Style & Reference \\
\hline 5-Level & Collins, 2001 \\
\hline Affiliative & Goleman, Boyatzis, \& McKee, 2004 \\
\hline Bureaucratic & Weber, 1905 \\
\hline Participative & Lewin, Lippitt, \& White, 1939 \\
\hline Servant & Greenleaf, 1977 \\
\hline Six Sigma & Pande, 2007 \\
\hline Transactional & Burns, 1978 \\
\hline Transcendent & Gardiner, 2006 \\
\hline Transformational & Burns, 1978 \\
\hline Visionary & Goleman et al., 2004 \\
\hline
\end{tabular}




\begin{tabular}{|c|c|c|c|c|c|c|c|c|c|c|c|c|c|c|c|c|c|c|c|c|c|c|c|c|c|c|c|c|c|c|c|}
\hline CSF (R...) & 1 & 2 & 3 & 4 & 5 & 6 & 7 & 8 & 9 & 10 & 11 & 12 & 13 & 14 & 15 & 16 & 17 & 18 & 19 & 20 & 21 & 22 & 23 & 24 & 25 & 26 & 27 & 28 & 29 & 30 & 31 \\
\hline Cultural Change & & & & $x$ & $\mathrm{x}$ & & & & $x$ & & $x$ & $x$ & & $x$ & $\mathrm{x}$ & & $\mathrm{x}$ & & $x$ & & & & & & $x$ & $\mathrm{x}$ & & $x$ & & $x$ & \\
\hline Leadership Style & & & & & & & & & & $x$ & $x$ & & & & & & & & & & $\mathrm{x}$ & & & & & & & & & $x$ & \\
\hline Management commitment & $\mathrm{x}$ & & $x$ & $\mathrm{x}$ & the & & & & $\mathrm{x}$ & & $x$ & $\mathrm{x}$ & $\mathrm{x}$ & $x$ & $\mathrm{x}$ & $\mathrm{x}$ & $\mathrm{x}$ & $\mathrm{x}$ & $\mathrm{x}$ & & & & & & $\mathrm{x}$ & & $\mathrm{x}$ & $\mathrm{x}$ & $x$ & $\mathrm{x}$ & $\mathrm{x}$ \\
\hline LSS Training & & $x$ & & $x$ & 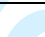 & 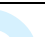 & $x$ & & $x$ & & $x$ & & $\mathrm{x}$ & $\mathrm{x}$ & $x$ & $x$ & & & $x$ & & $x$ & & $x$ & $x$ & $x$ & & $\mathrm{x}$ & $\mathrm{x}$ & $x$ & & $\mathrm{x}$ \\
\hline Organization infrastructure & & & & & 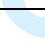 & $x$ & O & & $\mathrm{x}$ & & $\mathrm{x}$ & $\mathrm{x}$ & $\mathrm{x}$ & $x$ & & $x$ & & & & & & & & & & $x$ & & $\mathrm{x}$ & & & \\
\hline Communication & $x$ & & & & & & & & 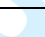 & & & $\mathrm{x}$ & & & & & & & & & & & & & & & & & $x$ & & \\
\hline Linking LSS to business strategy & & & $\mathrm{x}$ & $x$ & & $\mathrm{x}$ & & & & 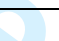 & & $\mathrm{x}$ & $\mathrm{x}$ & $\mathrm{x}$ & $\mathrm{x}$ & & $\mathrm{x}$ & & & & & & & & & & & $x$ & & & \\
\hline Linking LSS to customer & & & & & & & & & & & 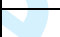 & $\mathrm{x}$ & & $\mathrm{x}$ & $\mathrm{x}$ & & $\mathrm{x}$ & & & & & & & & & & & $x$ & & & \\
\hline Linking LSS to HR rewards & $\mathrm{x}$ & & & & & & & & & & $\mathrm{x}$ & $\mathrm{x}$ & & $x$ & & & & & & & & & & $\mathrm{x}$ & & & & $\mathrm{x}$ & $x$ & & \\
\hline Extending LSS to supply chain & & & $x$ & & & & & & & & & $x$ & 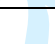 & $\mathrm{x}$ & & & & & & & & & & & & & & $\mathrm{x}$ & $x$ & & \\
\hline LSS projects prioritization & & & & $x$ & & & & $\mathrm{x}$ & $\mathrm{x}$ & & $\mathrm{x}$ & $\mathrm{x}$ & $x$ & $x$ & $\mathrm{x}$ & $x$ & & & & $\mathrm{x}$ & $\mathrm{x}$ & & & & $x$ & & & $\mathrm{x}$ & $\mathrm{x}$ & & $\mathrm{x}$ \\
\hline LSS projects tracking and review & & & & & & & & & & & & & $x$ & $x$ & & - & $x$ & & $\mathrm{x}$ & $\mathrm{x}$ & $\mathrm{x}$ & $\mathrm{x}$ & & & & & & & $x$ & & \\
\hline Project Management Skills & & & & $\mathrm{x}$ & & & & & & & & $\mathrm{x}$ & $\mathrm{x}$ & $\mathrm{x}$ & $\mathrm{x}$ & & & $\mathrm{x}$ & & $\mathrm{x}$ & & & & & & & & $\mathrm{x}$ & & & \\
\hline Tools and techniques & & & & $x$ & & & & & $x$ & & $x$ & & & $\mathrm{x}$ & $\mathrm{x}$ & & & 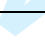 & & 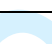 & & & $x$ & & & & & $\mathrm{x}$ & & & \\
\hline LSS financial accountability & & & & & & & & & & & & & $x$ & $x$ & $\mathrm{x}$ & & & & & 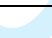 & $\bar{c}$ & & & & & & & & & & \\
\hline Data Based approach & & & & & & & & & $\mathrm{x}$ & & & & & & & & & & & & (e & & $x$ & & & & & & & & \\
\hline Communication and awareness & & & & & & & & & & & & & & & & & $\mathrm{x}$ & $\mathrm{x}$ & $x$ & & & & & & & & & $\mathrm{x}$ & & & \\
\hline Selection of staff for LSS & & & & & & & & & & & & & & & & & & & & $\mathrm{x}$ & $\mathrm{x}$ & & & & & & & & & & $\mathrm{x}$ \\
\hline Resources to LSS team & & & & & & & & & & & & & & & & & & & & & & & $x$ & $x$ & & & $\mathrm{x}$ & & & $x$ & \\
\hline
\end{tabular}




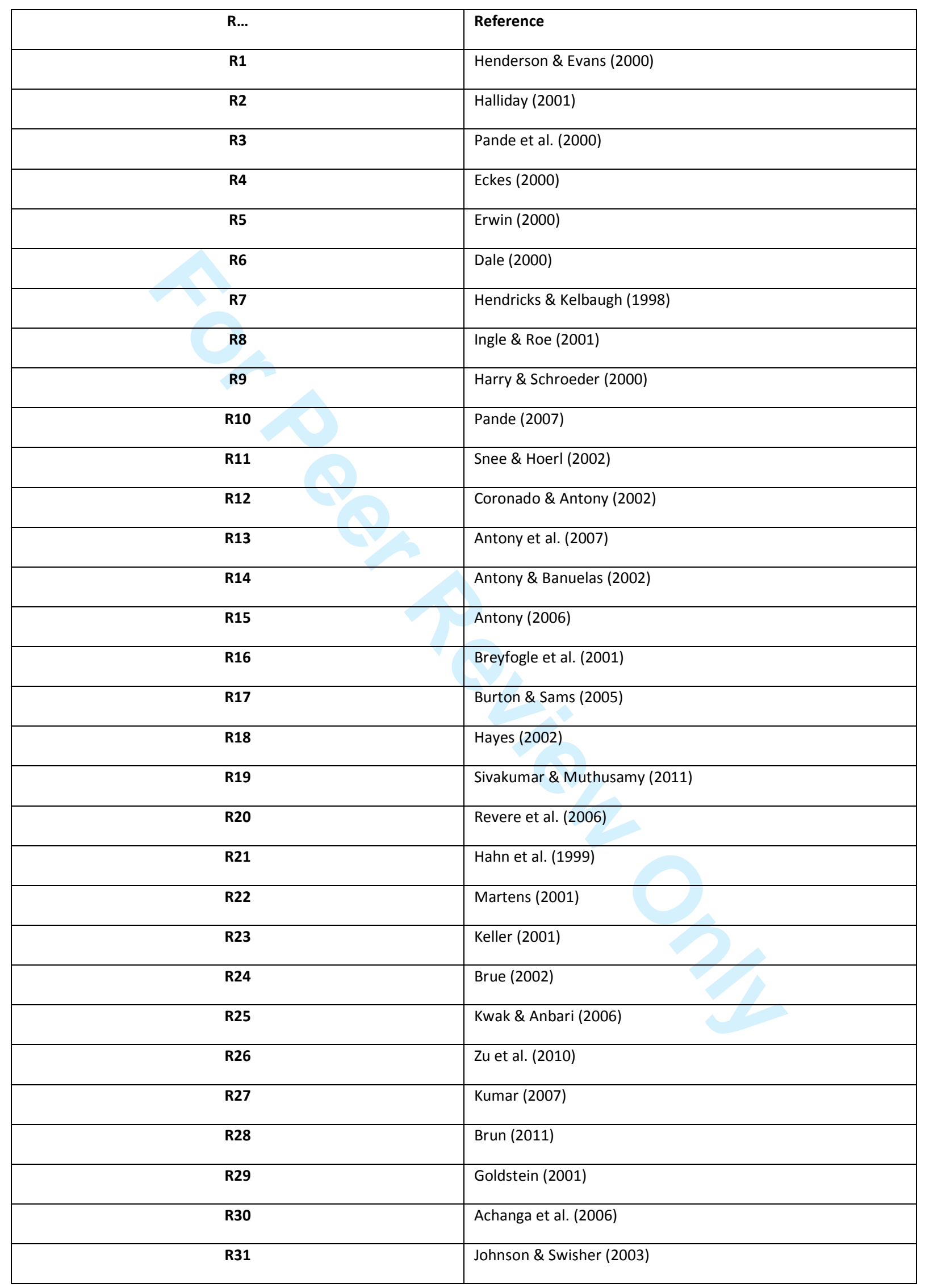




\begin{tabular}{|c|c|c|c|c|c|c|c|c|c|c|c|c|c|c|c|c|c|}
\hline 4 & $\begin{array}{l}\text { Cultural } \\
\text { Change }\end{array}$ & $\begin{array}{l}\text { Leadership } \\
\text { Style }\end{array}$ & $\begin{array}{l}\text { Management } \\
\text { commitment }\end{array}$ & $\begin{array}{l}\text { Organization } \\
\text { infrastructure }\end{array}$ & Communication & $\begin{array}{l}\text { Linking LSS to } \\
\text { strategy }\end{array}$ & $\begin{array}{l}\text { Linking LSS to } \\
\text { customers }\end{array}$ & $\begin{array}{l}\text { Linking LSS to HR } \\
\text { rewards }\end{array}$ & $\begin{array}{l}\text { Extending LSS } \\
\text { to supply chain }\end{array}$ & $\begin{array}{l}\text { LSS projects } \\
\text { selection }\end{array}$ & $\begin{array}{l}\text { Project Mgt } \\
\text { skills }\end{array}$ & $\begin{array}{l}\text { ISS Financial } \\
\text { accountability }\end{array}$ & $\begin{array}{l}\text { LSS projects } \\
\text { tracking }\end{array}$ & $\begin{array}{l}\text { LSS tools \& } \\
\text { techniques }\end{array}$ & $\begin{array}{c}\text { Data } \\
\text { based } \\
\text { approach }\end{array}$ & ISS Staff & $\begin{array}{c}\text { Resource } \\
\text { s to L ISS } \\
\text { staff }\end{array}$ \\
\hline Cultural Change & 1,000 & ,307 &, 350 & ,167 &, 203 &, 240 &, 273 &, 138 & ,309 & ,1966 &, 256 &, 116 &, 241 & ,193 &, 156 & ,177 &, 078 \\
\hline 9 Leadersip Style & ,307 & 1,000 & ,457 & ,105 &, 259 & ,368 & 324 & ,044 & ,384 &, 266 & ,147 & ,139 & ,181 &, 268 & ,148 & ,077 &, 174 \\
\hline $\begin{array}{ll}7 \text { Management } \\
\end{array}$ & , 350 & 457 & 1,000 & ,153 & ,387 &, 383 &, 409 & ,044 & ,213 & ,276 & ,105 & ,169 & ,201 & ,133 & $\begin{array}{l}, 062 \\
\end{array}$ & ,074 & ,045 \\
\hline 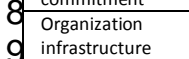 & , 167 & , 105 & ,153 & 1,000 &, 247 &, 012 &,- 047 & ,278 &, 200 &, 271 & ,275 & ,153 & ,095 &, 295 &, 231 & ,114 &, 144 \\
\hline Communication & ,203 &, 259 & ,387 & ,247 & 1,000 &, 261 &, 331 & ,150 &, 246 &, 390 &, 203 &, 188 &, 217 &, 201 & ,160 & 264 & ,287 \\
\hline $\begin{array}{l}\theta_{\text {Linking }} \text { LS to } \\
1 \text { strategy }\end{array}$ & ,240 & ,368 &, 383 & ,012 & 261 & 1,000 & ,473 & ,102 & 208 & 250 & 149 & ,249 & ,233 & ,195 & ,070 & 151 & ,217 \\
\hline 1 2customers &, 273 &, 324 & ,409 & -047 &, 331 &, 473 & 1,000 & ,155 &, 258 & ,195 & ,019 & ,188 & ,214 & ,153 & 249 & ,155 & ,172 \\
\hline $13_{\text {rewards }}^{\text {Linkin LS to HR }}$ & ,138 & ,044 & ,044 &, 278 &, 150 & ,102 & ,155 & 1,000 &, 377 &, 311 &, 334 &, 315 &, 242 & , 160 & ,094 & ,149 &, 124 \\
\hline $1 \sqrt{4 \text { Extededing LSS to }}$ & ,309 & ,384 & ,213 & ,200 & ,246 & ,208 & ,258 & ,377 & 1,000 & ,464 & ,407 & ,288 & ,268 & ,298 & 130 & ,350 & ,330 \\
\hline 155 ss projects & , 196 &, 266 &, 276 &, 271 &, 390 &, 250 & ,195 &, 311 & ,464 & 1,000 &, 558 &, 314 &, 314 &, 404 & ,286 &, 457 &, 402 \\
\hline 10 Project Mgt skills &, 256 & ,147 &, 105 &, 275 &, 203 &, 149 & ,019 &, 334 & ,407 &, 558 & 1,000 &, 474 & ,399 &, 365 &, 233 & ,399 &, 264 \\
\hline 1 17.ss $\quad$ Financial & (116 & 139 & ,169 & 153 & 188 & ,249 & 188 & ,315 & ,288 & ,314 & 474 & 1,000 &, 543 & ,223 & 115 & 309 &, 228 \\
\hline $\begin{array}{l}1 / Q_{25 s} \text { Projects } \\
\text { gracking }\end{array}$ &, 241 &, 181 &, 201 & 095 &, 217 &, 233 &, 214 &, 242 &, 268 &, 314 &, 399 &, 543 & 1,000 &, 314 & ,119 & ,374 &, 409 \\
\hline $\begin{array}{l}\text { LSS Tools \& } \\
\text { 20 Otechniques }\end{array}$ & 193 & 268 & ,133 & ,295 & 201 & 195 & 153 & 160 & ,298 & 404 & ,365 &, 223 &, 314 & 1,000 & ,355 &, 342 & ,259 \\
\hline $21_{\text {approach }}^{\text {Data }}$ based & , 156 & ,148 &, 062 &, 231 & , 160 & , 070 &, 249 & ,094 &, 130 &, 286 &, 233 &, 115 & ,119 &, 355 & 1,000 & ,250 &, 119 \\
\hline $2 \frac{2 p p r a d e n}{25 \text { section of LSS }}$ & , 177 & 077 & 074 & ,114 &, 264 &, 151 &, 155 &, 149 &, 350 &, 457 &, 399 &, 309 & 374 &, 342 & 250 & 1,000 &, 563 \\
\hline $23^{2}$ Resources to ISS & ,078 & ,174 & ,045 & ,144 & 287 & ,217 & ,172 &, 124 &, 330 & ,402 & ,264 & ,228 & 409 &, 259 & ,119 & ,563 & 1,000 \\
\hline
\end{tabular}

24 


\begin{tabular}{|c|c|c|c|c|c|c|c|}
\hline \multirow{2}{*}{ Factors } & \multicolumn{3}{|c|}{ Initial Eigenvalues } & \multicolumn{3}{|c|}{ Extraction Sums of Squared Loadings } & \multirow{2}{*}{$\begin{array}{l}\begin{array}{l}\text { Rotation Sum } \\
\text { Squared Loadings }\end{array} \\
\text { Total } \\
\end{array}$} \\
\hline & Total & $\%$ Variance & Cum $\%$ & Total & $\%$ Variance & Cum \% & \\
\hline 1 & 4,959 & 29,173 & 29,173 & 4,309 & 25,350 & 25,350 & 3,018 \\
\hline 2 & 1,901 & 11,183 & 40,355 & 1,241 & 7,297 & 32,647 & 2,821 \\
\hline 3 & 1,287 & 7,572 & 47,927 & 950 & 5,590 & 38,237 & 2,351 \\
\hline 4 & 1,172 & 6,896 & 54,823 & 697 & 4,103 & 42,340 & 2,330 \\
\hline 5 & 962 & 5,657 & 60,481 & & & & \\
\hline 6 & 904 & 5,319 & 65,799 & & & & \\
\hline 7 & ,867 & 5,102 & 70,901 & & & & \\
\hline 8 & ,775 & 4,560 & 75,462 & & & & \\
\hline 9 & 697 & 4,102 & 79,564 & & & & \\
\hline 10 & 622 & 3,658 & 83,223 & & & & \\
\hline 11 & ,553 & 3,250 & 86,473 & & & & \\
\hline 12 & ,484 & 2,849 & 89,322 & & & & \\
\hline 13 & ,465 & 2,738 & 92,060 & & & & \\
\hline 14 & 399 & 2,346 & 94,406 & & & & \\
\hline 15 & ,341 & 2,006 & 96,412 & & & & \\
\hline 16 & ,318 & 1,872 & 98,285 & & & & \\
\hline 17 & 292 & 1,715 & 100,000 & & & & \\
\hline
\end{tabular}




\begin{tabular}{|l|r|r|r|c|}
\hline & Factor & & & \\
\hline & 1 & 2 & 3 & 4 \\
\hline Project Management Skills & .611 & -.143 & & -.378 \\
\hline Lean Six Sigma Project Selection / Prioritization & .596 & .106 & .219 & \\
\hline Organizational Infrastructure & & & & \\
\hline Lean Six Sigma tools \& techniques & .464 & & & \\
\hline Extending Lean Six Sigma to Supply Chain & .426 & & .134 & \\
\hline Data-based approach & .393 & .201 & .155 & \\
\hline Linking Lean Six Sigma to HR rewards & .311 & & & \\
\hline Management Commitment & & .717 & -.147 & \\
\hline Linking Lean Six Sigma to Customers & -.148 & .674 & & \\
\hline Linking Lean Six Sigma to Business Strategy & -.113 & .588 & & -.136 \\
\hline Leadership style & .127 & .582 & & \\
\hline Communication & .187 & .387 & .170 & \\
\hline Cultural Change & .231 & .384 & & \\
\hline Resources to Lean Six Sigma staff & & & .893 & \\
\hline Selection of Lean Six Sigma staff & & & .537 & -.118 \\
\hline Lean Six Sigma Financial Accountability & & .126 & .251 & -.544 \\
\hline Lean Six Sigma Project tracking and review & & & \\
\hline Extraction Method: Maximum Likelihood. & & & \\
\hline Rotation Method: Oblimin with Kaiser Normalization. & & & & \\
\hline
\end{tabular}




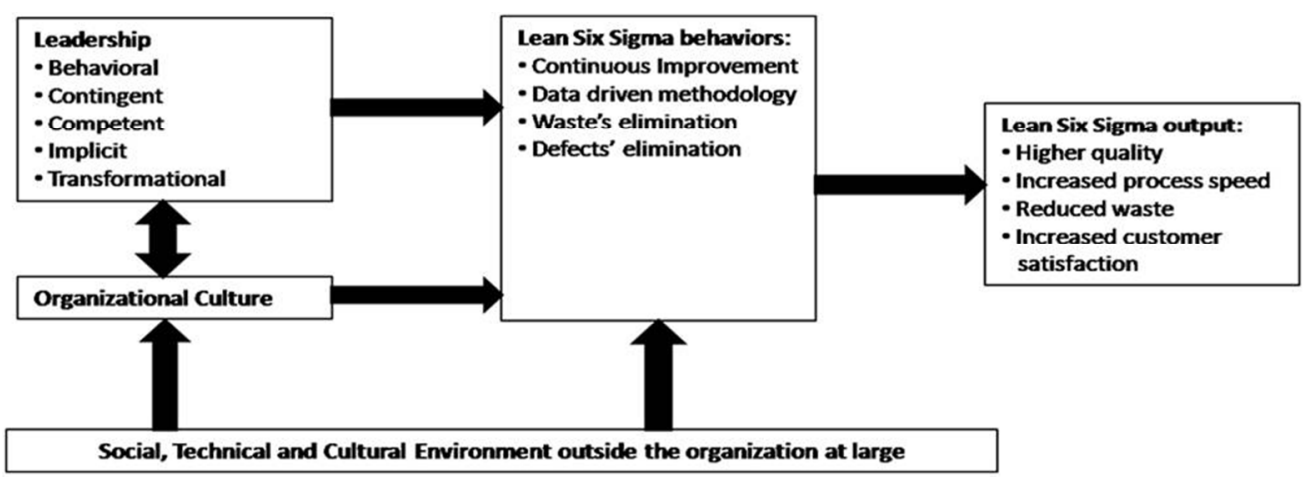

Model of leadership, culture and Lean Six Sigma, adapted from Waldman, 1993

$265 \times 94 \mathrm{~mm}(96 \times 96 \mathrm{DPI})$ 